University of Wollongong

Research Online

Faculty of Business - Papers (Archive)

Faculty of Business and Law

$1-1-2015$

The relationship between human capital, value creation and employee

reward

Peter R. Massingham

University of Wollongong, peterm@uow.edu.au

Wing Yin Leona Tam

University of Wollongong, Itam@uow.edu.au

Follow this and additional works at: https://ro.uow.edu.au/buspapers

Part of the Business Commons

Research Online is the open access institutional repository for the University of Wollongong. For further information contact the UOW Library: research-pubs@uow.edu.au 


\title{
The relationship between human capital, value creation and employee reward
}

\begin{abstract}
Purpose

This paper examines the relationship between human capital $(\mathrm{HC})$ and value creation and employee reward. $\mathrm{HC}$ is an important component of intellectual capital (IC). There is growing interest in how IC can be used to create organizational value. This paper addresses the need for critical analysis of IC practices in action. Based on data gathered from three annual surveys at Australia's second largest public sector organization, the paper introduces psychological contract as new HC factors, and develops a method to measure $\mathrm{HC}$ in terms of value creation (work activity) and employee reward (pay). The findings have practical implications for managers in using the paper's $\mathrm{HC}$ measurement to achieve strategic alignment of the workforce.
\end{abstract}

\section{Design/methodology/approach}

The research was based on data gathered from three annual surveys (2009-2011) of staff at Australia's second largest public sector organization. A total of 248 questionnaires were completed. Three independent variables conceptualised Human Capital: (1) employee capability (HC1), (2) employee satisfaction ( $\mathrm{HC} 2$ ), and (3) employee commitment (HC3). Two dependent variables were tested: (1) work activity and (2) pay. The data collected in this study was analyzed through the use of bivariate correlation and linear regression using SPSS software.

Findings

The paper's major finding is that $\mathrm{HC} 1$ (employee capability) and $\mathrm{HC} 2$ (employee satisfaction), had a direct positive relationship with the importance of work activity. The paper's second finding was that only HC1 has a direct positive relationship with the pay. However, HC3 (employee commitment) had a direct negative relationship with the importance of work activity. Further, $\mathrm{HC} 2$ and $\mathrm{HC} 3$ had no relationship with pay. The research project organization achieved strategic alignment with employees' capability and motivation; as well as employee capability and pay. However, inequities emerge in terms of employee commitment and value creation (work activity) and in the psychological contract factors and pay.

\section{Research limitations/implications}

While the research findings are limited by them being based on a single research project organization (RPO), this is offset to some degree by the longitudinal nature of the study and the size of the RPO. It also presents opportunities for further research, particularly in terms of further testing of the new conceptualization of $\mathrm{HC}$ in other organizations and industry settings, and investigation of the failed hypotheses: (a) PC and pay, and (b) employee commitment and work activity.

\section{Practical implications}

While strong PC employees are being asked to do important work, they are not always being paid at the rate of colleagues doing similar work. This will create perceptions of distributive justice, which will make those with strong PC unhappy, thereby decreasing their PC, disrupting the SA of the value creation, and lead to employee turnover. Managers can address this problem by using the $\mathrm{HC}$ method outlined in this paper to introduce methods such as merit increases and variable pay. While this is problematic for public sector organizations often constrained by having to fit salary awards, innovative organizations are increasingly considering more flexible pay systems.

\section{Originality/value}


The paper introduces a new conceptualization of $\mathrm{HC}$, and two proxies for organizational performance: pay and work activity. The paper addresses calls for IC in practice research to make the field more relevant for practitioners. The $\mathrm{HC}$ model introduced will allow managers to act on IC measurement by linking HC value with adequate pay, increasing motivation, commitment, and productivity, leading to increased innovation and reduced employee turnover.

\section{Keywords}

value, creation, human, relationship, employee, reward, between, capital

\section{Disciplines}

Business

\section{Publication Details}

Massingham, P. Rex. \& Tam, L. (2015). The relationship between human capital, value creation and employee reward. Journal of Intellectual Capital, 16 (2), 390-418. 


\section{THE RELATIONSHIP BETWEEN HUMAN CAPITAL, VALUE CREATION AND EMPLOYEE REWARD}

\section{Introduction}

This paper examines the relationship between human capital $(\mathrm{HC})$ and value creation and employee reward. Human capital is an important component of intellectual capital (IC). There is growing interest in how intellectual capital can be used to create organizational value. This paper addresses the need for critical analysis of intellectual capital practice in action. Based on data gathered from three annual surveys at Australia's second largest public sector organization, the paper introduces psychological contract as new human capital factors, and develops a method to measure human capital in terms of value creation (i.e., work activity) and employee reward (i.e., pay). The findings have practical implications for managers in using the paper's human capital measurement to achieve strategic alignment of the workforce.

The paper explores how public sector organizations may use intellectual capital by focusing on strategy execution and employee compensation. The outcome is strategic alignment of the workforce which creates value from intellectual capital via innovation. To achieve its aim, the paper is divided into three sections. The first section examines some of the literature surrounding intellectual capital and its challenges in the public sector, as well as the conceptualisations underlying this paper. The second section addresses the methodology used in this research project by describing the research frameworks containing the questions to be examined, the manner in which the data was collected and analysed, and the findings. The third section of this paper provides a discussion of the results and the implications for intellectual capital research and those interested in using intellectual capital in practice.

The practical implications of the paper focus on what to do if organizations find their workforce is not strategically aligned. The findings at the research project organization showed that while employees with strong psychological contract (PC) with their organization, i.e. happy and loyal, are being asked to do important work, they are not always being paid at the rate of colleagues doing similar work. This will create perceptions of distributive justice, which will make those with strong PC unhappy, thereby decreasing their psychological contract, disrupting the strategic alignment of the value creation, and lead to decreased innovation and employee turnover. Managers can address this problem by using the human capital conceptualization outlined in this paper to introduce initiatives such as merit increases and variable pay. While this is problematic for public sector organizations 
which often are constrained by having to fix salary rewards, innovative organizations are increasingly considering more flexible pay systems.

The paper's originality lies in a re-conceptualization of human capital. The paper addresses calls for intellectual capital research to make the field more relevant for executives and practitioners. The human capital conceptualization introduced here will allow managers to act on intellectual capital measurement by linking human capital value with adequate pay; increasing motivation, commitment, and productivity, achieving strategic alignment in the workforce, leading to increased innovation and reduced employee turnover.

\section{The Third-Wave of Intellectual Capital Research}

The theory of intellectual capital emerged in the early 1990s in response to growing interest in intangible assets. There have been three stages of intellectual capital research. The first stage was the development of a measurement framework (Guthrie and Petty, 2000). For example, Sveiby (1997) classified intellectual into three components: (1) internal structure, (2) external structure, and (3) employee competence. The most widely used classification is Stewart's (1997) model of (1) human capital, (2) structural capital (sometimes called organizational capital), and (3) customer capital (sometimes called relational capital). The second stage of intellectual capital research used these frameworks to empirically measure the value of intellectual capital and how this can be achieved in practice. This research included content analysis of company annual reports and the use of various methodologies claiming to value intellectual capital; but this research has been criticised as "over used, and lacking in new contributions and validity" (Dumay, 2014, p. 3). There is recent interest in other capitals and how these can be used to create organizational value (Abeysekera, 2013). While various classifications of intellectual capital have served the field well, they are broad and abstract concepts. It is crucial to operationalize them so that they can be translated into management action.

The third stage of intellectual capital research is more practice-focused, "based on a critical and performative analysis of intellectual capital practices in action" (Guthrie et al., 2012, p. 69). There is growing interest in how intellectual capital can be used to create organizational value (Abeysekera, 2013). Intellectual capital is increasingly used as an analytic tool to assist strategic planning involving better management of intangible assets (Whyte and Zyngier, 2014). However, there is a need to translate this research into practical management guidelines so that managers can see how to use intellectual capital. Only then will intellectual capital practices in action be seen by management to create value. Associated with this theme is the timeliness of intellectual capital reporting. Dumay 
and Tull (2007) argue that more frequent disclosure of intellectual capital would provide higher immediacy value, which is particularly relevant if our aim is to improve perception of intellectual capital in practice.

This paper is targeted at the 'third-wave' of intellectual capital research, amid calls from the editor of the Journal of Intellectual Capital (JIC), Mr Rory Chase, for intellectual capital to be more performative (cited in Dumay, 2014), which in this paper we interpret as being about actions or intellectual capital in practice, and for intellectual capital researchers to develop new models that help better understand how intellectual capital works and is managed within an organisation (Dumay, 2014). Much of intellectual capital research has focused on measuring and reporting the quantitative value of intellectual capital (Dumay, 2014), which is an admirable goal due to the growing need to measure intangible assets like knowledge (Guthrie et. al., 2006).

The field appears to have become stuck in the pursuit of measurement constructs and quantitative values, and its main journal JIC seems to have been type-cast as an accounting journal (Dumay, 2014). Mr Chase has asked researchers to broaden their focus and look at a more managerial perspective, particularly in terms of how intellectual capital is or can be applied. Intellectual capital researchers are increasingly using the terms - manage and measure - together in their discussion of intellectual capital and its future (e.g. see Cleary, 2009; Sillanpa“a” et al. 2010; and Dumay and Rooney, 2011). In their discussion of the internationally recognised public sector intellectual capital leader - the Land and Property Authority of NSW (Lands), Dumay and Rooney (2011) explain that there is an increasing tension in public sector organizations to find a balance between measuring and managing intellectual capital. They raise a thought provoking question: Is intellectual measurement necessary for the effective management of intellectual capital? They link their discussion to Drucker's (1954) pioneering concept of management by objectives. The focus on measuring intellectual capital seems to have been driven by a loose assumption that what gets measured gets managed. There is increasing doubt that the measurement of intellectual capital, in isolation, creates value. However, most organizations comes up short in actions after obtaining measured values of intellectual capital.

An important challenge for intellectual capital research is the inability of the field to identify a set of measures which are widely accepted and adopted. The field's focus on measurement appears to suggest that it must get "accurate" intellectual capital measures before progressing to managing intellectual capital. As no consensus on the measures has been reached, intellectual capital research risks becoming stagnant or being dismissed, intellectual capital is seen as an abstract idea that cannot be acted upon. This risk is generated because action, rather than measurement, is the way to create organizational value. Public sector organizations likes Lands (a State Government agency) 
have tackled this problem by focusing on narrative rather than measurement. Lands appear to have given up on measuring intellectual capital and are now focused on reporting how they are mobilising resources - intellectual capital practices - rather than accounting for intellectual capital (see Dumay and Rooney, 2011).

\section{Managing Intellectual Capital}

The third wave of intellectual capital research aims to persuade managers to use intellectual capital. Marr (2003) identified five main reasons why organisations measure and report their intellectual capital:

(1) To help organisations with strategy formulation.

(2) To help assess strategy execution.

(3) To assist in strategic development, diversification and expansion decisions.

(4) As a basis for employee compensation.

(5) To communicate with external stakeholders.

It is the fourth issue, the use of intellectual capital as a basis for employee compensation, that is the primary focus of this paper, with a secondary focus on the second issue, to use intellectual capital to help assess strategy execution. The reason for this focus is provided via the evolution of Kaplan and Norton's Balanced Scorecard (BSC) (e.g. see Kaplan and Norton, 1996). When the BSC first emerged, it was seen as a measurement model. The BSC argued 'what you measure is what you get' (Kaplan and Norton, 1992). However, over time, the BSC has evolved and Kaplan and Norton saw that the real value in the BSC was in strategy execution. In this paper, we examine these two foci to examine how intellectual capital may be used to achieve strategic alignment. Strategic alignment occurs when the organization aligns its people, systems, and culture to execute its strategy (Kaplan and Norton, 2006). Strategic alignment is the proxy for performance that will enable increased innovation and productivity. We will examine how intellectual capital may be used to achieve SA within their workforce.

\section{The Public Sector and Intellectual Capital}

As this JIC Special Issue examines intellectual capital and the public sector, we will present our research findings within this context. Public sector organizations present interesting challenges for intellectual capital. While intellectual capital has been embraced by many federal government 
agencies, it has had less take-up at the state and local government levels (McNabb, 2007). Dumay and Rooney's (2011) study of Lands - a State Government agency - demonstrates how even a best practice public sector intellectual capital leader can struggle to find an appropriate balance between measurement and management of intellectual capital. In the case of Lands, they have focused on the mobilisation of intellectual capital, rather than reporting measured values, and in doing so have concentrated on intellectual capital practice via narratives of achievement (Dumay and Rooney, 2011). It seems that Lands have achieved this transition from measurement to action by adapting the BSC to suit their needs. We follow the same approach in this paper.

Researchers have argued that intellectual capital can gain traction in the public sector if managers are persuaded to focus on innovation (McNabb, 2007). Innovation is the process of creating something different; it occurs with the conversion of existing knowledge and ideas into new benefit, such as new or improved products, services or business processes (McNabb, 2007). In the public sector, innovation typically involves new technologies, service delivery, or new processes or systems (Edvinsson et. al., 2004).The measurement and management of innovation may be achieved via the BSC's learning and growth dimension (L\&G). It is here where we believe the management of intellectual capital will create most value; as a tool to adapt the BSC's L\&G dimension to mobilise innovation.

\section{Human Capital}

Intellectual capital is typically defined as the sum of an organisation's resources encompassing knowledge, information, intellectual property, experience, and any intellectual resource that can contribute to value creation for the organisation (Bontis, 2002). Intellectual capital encompasses three primary interrelated components: human capital, structural capital and relational capital (Sveiby, 1997). Human capital represents the human factor in the organization: the combined intelligence, skills, and expertise that give the organization its distinctive character (Bontis 1998). Researchers argue that human capital is the firm's most important asset because it is the source of creativity and, therefore, innovation, change, and improvement (Carson et al, 2004). Given this paper's proposition that innovation represents an opportunity to create value from intellectual capital in practice, we focus on human capital as the source of innovation.

The conceptualization of human capital presented in this paper is new. We are not aware of other research which has defined human capital in this way. The conceptualization is based on combining conventional views on human capital with the individual's emotional relationship with their organization. Psychological contract is the emotional relationship between the individual and 
employer and measures organizational commitment (Massingham and Diment, 2009). PC may be understood within the motivational processes of social exchange theory and the norm of reciprocity (e.g. Blau, 1964; Homans, 1961). The origins of psychological contract come from the work of Argyris (1960), who used the term to describe the relationship between a group of employees and their supervisor. Psychological research on mental models of employees, promise-making, mutuality, and affective attachment are considered the building blocks for psychological contract theory (Rousseau, 2001). The construct was further developed to describe a set of unwritten expectations and subjective beliefs that exist between employees and their employers and govern the continuing development of the employment relationship, which evolves over time. This paper divides PC into two factors: employee satisfaction and employee commitment. While both factors capture the employees' emotional relationship with their organization, the former measures whether the individual is happy and the latter measures whether they are willing to stay.

The conceptualisation presented in this paper is that HC comprises of three sub-constructs: employee capability, employee satisfaction, and employee commitment. The first is based on intellectual capital theory, while the other two are based on psychometric theory. Psychometric theory examines the psychology of human behaviour at work. The measurement used for employee satisfaction and employee commitment used well established instruments from psychometric theory including Eisenberger et al (1990) and Robinson and Rousseau (1994). Employee satisfaction and commitment are used as proxies for PC. Employee satisfaction refers to whether the employee is happy at their workplace and employee commitment focuses on how willing they are to stay. Employees who are happy and want to stay for the long term are defined as having strong PC, and more likely to have positive work attitudes and engage in behaviours creating value from their knowledge for their organization. The conceptualization is that employee capability is influenced by employee satisfaction and commitment. Employee capability may or may not generate value. It is only when individuals are motivated to use their knowledge that it creates organizational benefit, otherwise it is an idle resource.

Employee capability is the type of knowledge typically explained in response to the question: what do you know? It is the core of job interviews. It often begins with what you can do such as how long you have been doing it (experience), how good you are at it (skills), how much training you have had (qualifications), and the level of competency you have reached (knowledge). It is defined as technical knowledge. It may be referred to as 'hard' competency. It may also be considered subject matter expertise. Employee capability focuses on what you have learned to do a job. Examples include disciplines such as marketing, electrical engineering, accounting or nursing; tasks such as marketing 
plans, risk assessment, monthly reports, or inserting an injection; or domains (knowledge base) such as communication, mathematics, statistics, or health care.

In this paper, employee capability is conceptualised as something that tends to increase over time, often quite naturally without any intervention. For example, capability tends to increase over time as you become better at doing something (i.e. specialisation); experience accrues over time, skills tend to get better with more practice (i.e. learning curve), qualifications tend to build up over time due to staff training and other organizational learning opportunities, and knowledge levels usually move forwards unless the knowledge becomes obsolete.

Therefore, employee capability is the platform for human capital and, indeed, intellectual capital. It identifies the potential value of an individual for an organization. Like an IQ score is an individual's potential to learn, the employee capability score is the potential to create value from knowledge. Knowledge, like any organizational resource, only creates value when it is combined with other resources to develop organizational capabilities (Grant, 2014). In other words, knowledge creates value through its use. This explains why we describe employee capability as identified potential rather than actual value. Employee capability measures what the individual knows, at the most fundamental level, but not whether they will use it. We now turn to employee satisfaction and commitment to show how they combine with employee capability to determine the individual's value to the organization.

Employee satisfaction and commitment are about taking action. While employee capability may measure an individual's overall competence, it does not guarantee that the person will actually use their knowledge to create value for the firm. Employee satisfaction and commitment refer to the individual's emotional relationship with the organisation and help us understand whether they will use and share their knowledge. Brilliant people, i.e. individuals with very high technical knowledge and even job-related knowledge, may be very unproductive if they do not want to use or share their knowledge due to a low psychological contract score (i.e. they are unhappy). Employee satisfaction and employee commitment address an inherent weakness in intellectual capital theory, that is, it does not cater to changes in cognition or behaviour (Bontis, 2002). Employee satisfaction and commitment identify individual level motivation barriers (e.g. locus of control), as well as barriers created by the organisation (e.g. calculative reward), and management (e.g. trust).

Employee satisfaction is less obvious to others. It is about whether the individual is happy at the firm. Employee satisfaction does more than identify whether people they like what they do. It measures how they feel about the place where they work. For example, an individual might like being an accountant but hate where they work as an accountant. It is this emotional relationship 
with the firm that is often hidden from others and can lead to a lack of creativity and sharing necessary to generate value from employee capability.

Employee Commitment is the least obvious of our $\mathrm{HC}$ constructs. It measures whether the individual is likely to stay at their organization. Individuals who feel they have a long term future at their organization are more likely to commit to behaviours and attitudes aligned with its goals and success. These individuals are more likely to cooperate with management, engage in change, share experience, and grow their organization-specific capabilities. In other words, they are knowledge workers that can improve an organization's learning organisation capacity.

More details on these constructs and the literature used are provided in table 1.

Please insert table 1 about here

\section{Research Questions}

The desired outcome of this study was to examine the relationship between human capital, value creation, and employee reward. This will explore how public sector organizations may use intellectual capital by focusing on strategy execution and employee compensation. The outcome is strategic alignment of the workforce which demonstrates value from intellectual capital via innovation. This involves several constructs and research questions.

The first step was to conceptualise the relationship between intellectual capital and innovation. We did this by focusing on human capital. We began by measuring the value of $\mathrm{HC}$ in ways that could help managers understand the contribution of $\mathrm{HC}$ to innovation. This contribution was grounded in the individual's willingness to use their knowledge to create and share with others in the pursuit of innovation; typically new technologies, service delivery, or new processes or systems (Edvinsson et. al., 2004). The use of knowledge brings into play attitudes and behaviours. An individual might have very strong competence, e.g. qualifications and experience, but this knowledge might remain idle if he/she is unwilling to use it. Attitudes and behaviours may be explained by the individual's emotional relationship with their organization. This led us to propose that IC's definition of HC might be enhanced by psychological contract factors. In this way, we contributed to Abeysekera's (2013) call for identification of 'other capitals' to understand the value of IC, by extending the conceptualization of $\mathrm{HC}$. Thus the first research question is:

RQ1: Do psychological contract factors, such as employee satisfaction and employee commitment, improve our understanding of how HC contributes to innovation? 
The second step was to conceptualise the relationship between intellectual capital and strategy execution. We did this by focusing on value creation. In this paper, value was defined by the work activities performed by employees. The resource-based view of the firm and the knowledge based view of the firm (see Grant, 2014) help us understand that human capital creates value for the organization by combining with other resources to generate capabilities. The value created is heterogeneous depending upon the organizational context and the activity. This allowed us to differentiate between activities in terms of their importance. Thus the second research question is:

RQ2: Is there any relationship between (conventional) HC and the value of work created for theorganization?

Work activity also has a relationship with employee motivation. Psychometric theory introduces factors such as locus of control (Porter et al. 1973) and personal outcome expectancy to measure employees' sense of autonomy and whether they feel their work is important and has meaning. The human resource management literature's job enrichment theory helps link our value factor - work activity - with the PC factors. This literature argues that opportunities to work on challenging assignments or difficult work are positively related to organizational commitment and intention to stay (Chew and Chan, 2008). For example, studies involving technical workers (e.g. Workman and Bommer, 2004) have found that employees who are offered challenging, exciting and interesting work tend to be more involved and satisfied, and are in turn more committed to their organization and are less likely to leave their organization. Research has found that employees might hold such attitudes because it indicates good career management leading to a fulfilment of psychological contract (Sturges et al., 2005). Thus the third research question is:

RQ3: Is there any relationship between psychological contract factors, such as employee satisfaction and employee commitment, and the value of work created for the organization?

The third step was to conceptualise the relationship between intellectual capitaland employee compensation. We did this by focusing on pay scales. Pay is defined as the wages, salary or compensation given to an employee in exchange for services the employee performs for the organization (Phillips and Connell, 2003). Research has found that pay is an implied agreement between an employer and an employee which recognises the individual's value to the organization (Chew and Chan, 2008). In this way, pay is a proxy for how the organization values HC. Organizations need a pay system that is fair, equitable, and competitive (Phillips and Connell, 2003). From an intellectual capital perspective, people need to be rewarded for their competencies. In the public sector, this is typically done by pay schedules, which is the pay at various levels in the organization, which is published and transparent. 
There are two ways that intellectual capital can deliver value in terms of employee compensation: (1) equity and (2) employee turnover. Intellectual capital can assist managers and employees see equity in their pay by measuring competencies. If employees perceive inequity, there will be dissatisfaction with pay which is one of the main causes of employee turnover. Intellectual capital an help by ensuring employee performance is linked to pay, thereby reducing inequity and ET. Thus the fourth research question is:

\section{RQ4: Is there any relationship between (conventional) HC and employee compensation?}

Equity involves employee perceptions about the fairness of pay and whether they feel they are being paid what they are worth in comparison to colleagues. Inequity suggests unfairness and leads to employee turnover. Although pay is recognized as an antecedent of organizational commitment and intention to stay, research has found that pay alone is not sufficient (Chew and Chan, 2008) and intrinsic factors also contribute. We see this as employees need to be recognised and rewarded for their motivation (employee satisfaction) and organizational commitment. Therefore, this provides a link between our reward factor - pay - and the psychological contract factors. Thus the fifth research question is:

RQ5: Is there any relationship between psychological contract factors, such as employee satisfaction and employee commitment, and employee compensation?

Now that the questions needing examination have been identified, the manner in which the study will be conducted and the source of our data must be outlined in relation to the framework of these five questions. We build connections between human capital, strategic alignment, and innovation via two output variables: pay and work activity. Work activity is the measure of value created by human capital. Pay is the measure of the organization's reward to employees for creating this value. Strategic alignment is achieved if the right people are focused on the right activities at the right time and they are rewarded appropriately for doing so. Innovation and efficiency will then result. Strategic misalignment occurs if employee capability and psychological contract do not match work activity and or pay does not match the value created. The result is then demotivation, unproductivity, and employee turnover. The public sector presents an interesting challenge for this study, particularly because pay is something that is usually fixed to a schedule, e.g. an award, and allows managers little flexibility. An important question is whether public sector pay schedules pose a barrier for achieving strategic alignment from human capital. This can be seen in Figure 1.

Please insert figure 1 about here 


\section{Methodology}

\section{Research Project}

The study was funded by the Australian Research Council (ARC) and a large public sector department. It aimed to measure and manage the impact of organizational knowledge loss. The organization participating in the study was selected because it was a knowledge-intensive organization, with an ageing workforce. In terms of the justification for the study, the research project was a large-scale longitudinal study of organizational change. It is rare for researchers to gain deep access to organization over a period of six years. This provided rich empirical data which allowed us to track change over the life of the project (2008-2013). Intellectual capital was not the focus of the project; it was simply part of a much broader project. The first purpose of the project was to develop measures to understand the nature of knowledge loss. The second purpose was to introduce a range of research interventions designed to manage the impact of knowledge loss. A third purpose was to evaluate the relationships between the first and second parts, that is, to track how well the interventions were doing against the measurement indicators. This was a very big project which produced much data and findings. The results presented in this paper represent just one set of data. The intellectual capital in practice is mainly positioned within the first part - a component of the measurement of knowledge loss - but also linked to the second (managing) and third (performance) parts via our attempts here to explain how intellectual capital is useful to managers. The themes explored later in this paper, such as productivity, motivation, morale, employee turnover, are all very relevant to the broader aims of the research project. This situates the findings presented in this paper within the very real context of public sector managers using intellectual capital to deal with significant organizational problems.

The study involved three annual surveys. An invitation and cover letter explaining the study and assuring confidentiality were sent via email to all 150 engineering and technical staff at the research project organization (RPO). Therefore, the entire population was included in the study. Respondents were asked to complete and submit the surveys on-line. Both management and staff participated in the survey. The survey was conducted in late 2009, 2010, and 2011 . This allowed the survey results to be tracked over time and for the validity of the constructs to be tested in a 3 year longitudinal empirical study. The response rates were 79\% (2009), 46\% (2010), and 72\% (2011). These were excellent participation rates given the study was entirely voluntary and the survey was onerous, i.e. it took 7 hours on-line to complete. The lower participation in 2010 was due to organizational upheaval caused by a restructure. The survey results were analysed and the findings reported to management. 
Measures

A survey was designed that draws on the intellectual capital and the psychometric literatures, within the context of the literature review and the conceptual model. Previous instruments were replicated, wherever possible. For the majority of the questions, respondents were asked to indicate the extent of their agreement on a six-point Likert scale ( 1 = strongly disagree, 6 = strongly agree). Scale items with low item-total correlations (below 0.3) were omitted to obtain the satisfactory construct reliability with Cronbach's alpha of 0.7 or above (Nunally, 1978). Principle component analysis with varimax rotation (where necessary) was run to check the construct validity (Hair et al. 1995). Items with factor loadings lower than 0.3 were deleted to improve the validity.

With this framework in mind, the manner in which the data was collected and processed to answer the questions posed is now explained.

\section{Data Collection and Processing}

There are two dependent variables in this study: pay scale and activity level. Pay scale was reported directly from the respondents as their annual salary before taxes in dollars. Activity level was measured by combining importance by time spent. Importance was measured by asking RPO executive managers to rate 128 activities performed by employees on a five point scale, where $1=$ not important and $5=$ critical importance. The ratings were based on perception of the value created for the organization using the principles of distinctive and core competence. Respondents were asked to indicate how much time they spent on each activity. An activity score out of 100 was then calculated by multipolying time spent by importance rating. For example, an individual spending $100 \%$ of time on level 5 activities gets a score of 100; an individual spending $50 \%$ of time on level 5 activities and $50 \%$ on level 4 activities gets a score of 90 ; an individual spending $40 \%$ of time on level 3 activities, $30 \%$ on level 2 , and $30 \%$ on level 1 gets a score of 42 , and so on. Employees spending a high proportion of their time on very important activities are more valuable. For both dependent variables - pay and activity - face value validity was used based on expert opinion, i.e. the RPO executive.

The independent variables in this study are the three types of human capital $(\mathrm{HC})$ which are labelled as $\mathrm{HC} 1, \mathrm{HC2}$, and $\mathrm{HC} 3$ to represent employee capability, employee satisfaction, and employee commitment respectively. In most cases, 6-point Likert scale anchored from strongly disagree to strongly agree were used. Items were averaged to form an index. This paper is not about measuring the value if IC. We use a scoring method based on recent research (Massingham, 2014) only to 
provide the data for our conceptualization of HC. Scores out of 100 are then able to be allocated based on the value of the individual's knowledge. Please refer to table 1 above for further details of the measures.

\section{Analysis}

In order to test our hypotheses, the data collected in this study was analyzed through the use of bivariate correlation and linear regression using SPSS software. We begin with descriptive and correlation statistics.

Table 2 reports the descriptive statistics of the study. The average annual salary was AUD\$86241 with a standard deviation of AUD\$23223. The average activity level was 52.26 with a standard deviation of 15.86 . The mean levels of the employee capability, employee satisfaction, and employee commitment HC dimensions were 53.86\% ( $\mathrm{SD}=9.79$ ), 62.62 ( $\mathrm{SD}=10.64)$, and 65.29 $(S D=13.81)$ respectively. The averages of the independent variables ranged from $31.5 \%$ to $74.51 \%$.

Please insert table 2 about here

Table 3 also presents the Pearson bivariate correlation among the independent and dependent variables. Multi-collinearity is not a concern in this study as the maximum Pearson correlation values are below the critical value of 0.8 (Hair et al., 1995).

Please insert table 3 about here

Pay scale and activity level were used as dependent variables in two separate regression models with the same independent variables as shown in the model above.

The main linear regression model is:

$D V=\alpha+\beta 1 H C 1+\beta 2 H C 2+\beta 3 H C 3+e$

\section{Question 1.}

$\mathrm{H}_{1}$ : Effect of psychological contract and innovation.

This hypothesis will test the first research question and is presented as follows: 
Ho: The human capital 1 score, the human capital 2 score, and the human capital 3 scores are not all positively related to activity level

HA: The human capital 1 score, the human capital 2 score, and the human capital 3 scores are all positively related to activity level

As shown in the results above in Table 3, employee capability (human capital 1) and employee satisfaction (human capital 2) have significant and positive relationships (employee capability: $\mathrm{t}=3.20, \mathrm{p}<.001$; employee satisfaction: $\mathrm{t}=3.98, \mathrm{p}<.001$ ) with activity level while employee commitment (human capital 3) has significant but negative relationship with activity level ( $t=-2.60$, $\mathrm{p}<.001)$.

These results provide support to the null hypothesis and for concluding that not all human capital scores have a positive relationship with activity level. All three human capital scores have significant impact on value creation for the organization. More specifically, we found that the more capable the individual is or the happier the individual is at work, the more likely they are to spending more time doing more important work, i.e., creating more value for their organization. On the other hand, the more committed an individual is, the individual is more likely to spend more time doing less important work. This latter result is counter-intuitive as we would expect that committed individuals would be doing important work. However, it is explained by a peculiar aspect of the RSO sample: respondents with higher commitment tended to be younger and more junior employees doing less important work (due to inexperience); while respondents with lower commitment tended to be older and more senior and were doing more important work (due to experience). This occurred because many of the latter group of respondents intended to retire which meant they had low commitment in terms of their future with the organization. This is explained further later (see $\mathrm{H}_{3} b$ ).

H1b: Effect of psychological contract and innovation.

This hypothesis will also test the first research question and is presented as follows:

Ho: The human capital 1 score, the human capital 2 score, and the human capital 3 scores are not all positively related to pay scales

HA: The human capital 1 score, the human capital 2 score, and the human capital 3 scores are all positively related to pay scales

As shown in Table 3, employee capability is the only human capital that has significant and positive relationship with pay scales $(t=4.118, p<.001)$. Employee satisfaction $(t=0.29, p>.77)$ and employee commitment $(t=0.76, p>$.44) have positive relationships with pay scales. However, the positive relationships are not statistically significant. Therefore, there is not sufficient support to reject the 
null hypothesis. The results show that the higher the individual employee's capability is, the more likely the individual will be rewarded. However, the levels of how satisfied or how committed an individual is with the organization do not have significant impact on the likelihood of being rewarded for their work.

\section{Question 2.}

H2: Effect of (conventional) human capital and value creation (activity).

This hypothesis will test the second research question and is presented as follows:

Ho: The human capital 1 score, i.e. overall mean score for employee capability, is not positively related to activity level.

HA: The human capital 1 score, i.e. overall mean score for employee capability, is positively related to activity level.

These results provide support for rejecting the null hypothesis and for concluding that there is a positive relationship between employee capability and activity level. In other words, the higher the individual's capability, the more likely they are to spend more time doing important work, i.e. creating value for their organization.

This finding is consistent with conventional views of human resource management. Employees are usually allocated more complex work as they gain experience, qualifications, and competency. The typical perception of human capital - employee capability (HC1) - has a significant and positive impact in predicting activity level.

\section{Question 3.}

$\mathrm{H}_{3 \mathrm{a}}$ : Effect of psychological contract and value creation (activity).

This hypothesis will test the third research question and is presented as follows:

Ho: The human capital 2 score, i.e. the overall mean score for employee satisfaction, is not positively related to activity level

HA: The human capital 2 score, i.e. the overall mean score for employee satisfaction, is positively related to activity level

Employee satisfaction (HC2) was statistically significant in predicting activity level, and had positive impact. 
These results provide support for rejecting the null hypothesis and for concluding that there is a positive relationship between employee satisfaction and activity level. In other words, the happier the individual is at work, the more likely they are to spend more time doing important work, i.e. creating value for their organization.

$\mathrm{H}_{3} \mathrm{~b}$ : Effect of psychological contract and value creation (activity).

This hypothesis will also test the third research question and is presented as follows:

Ho: The human capital 3 score, i.e. the overall mean score for employee commitment, is not positively related to activity level

HA: The human capital 3 score, i.e. the overall mean score for employee commitment, is positively related to activity level

Employee commitment (HC3) showed a significant and negative impact on the amount of time that employees spent on more important tasks.

Therefore, these results provide support for the null hypothesis and for concluding that there is not a positive relationship between employee commitment and activity level.

This finding is counter-intuitive and is explained by the peculiar nature of the workforce at the research project organization (RPO). As many of the most experienced staff were due to retire, their commitment to the organization was low. They answered questions like "will you be working at the RPO in five years?" with no. However, as the most capable staff, they were given the most important activities to do. On the other hand, younger staff who were more likely to answer the above question with yes, were doing less important work because they were less capable, not because of their commitment levels.

\section{Question 4.}

H4: Effect of human capital and employee compensation (pay).

This hypothesis will test the fourth research question and is presented as follows:

Ho: The human capital 1 score, i.e. overall mean score for employee capability, is not positively related to pay scales.

HA: The human capital 1 score, i.e. overall mean score for employee capability, is positively related to pay scales.

These results provide support for rejecting the null hypothesis and for concluding that there is a 
positive relationship between employee capability and pay scales. In other words, the higher the individual's capability, the more likely they are to be paid more, i.e. being rewarded for creating value for their organization.

This finding is consistent with conventional views of human resource management, where there must be a clear link between organizational performance and the pay structure (Phillips and Connell, 2003). The typical perception of human capital - employee capability (HC1) - has a significant and positive impact in predicting pay scales.

\section{Question 5.}

H5a: Effect of psychological contract and employee compensation (pay).

This hypothesis will test the fifth research question and is presented as follows:

Ho: The human capital 2 score, i.e. the overall mean score for employee satisfaction, is not positively related to pay scales

HA: The human capital 2 score, i.e. the overall mean score for employee satisfaction, is positively related to pay scales

Employee satisfaction ( $\mathrm{HC2}$ ) showed a positive though not significant impact on pay scales.

These results do not provide support to reject the null hypothesis, and conclude that there is a positive relationship between employee satisfaction and pay scales, but this positive relationship is not statistically significant. In other words, there is no significant relationship between how happy the individual is at work and the likelihood they are to be rewarded for resulting positive work attitudes and behaviours. Individuals at high pay scales could be as happy as those at low pay scales, and vice versa; there was no clear pattern.

$\mathrm{H}_{5 b}$ : Effect of psychological contract and employee compensation (pay).

This hypothesis will also test the fifth research question and is presented as follows:

Ho: The human capital 3 score, i.e. the overall mean score for employee commitment, is positively related to pay scales

HA: The human capital 3 score, i.e. the overall mean score for employee commitment, is not positively related to pay scales

Employee commitment (HC3) showed a positive but insignificant impact on pay scales. 
These results do not provide sufficient support for rejecting the null hypothesis, and conclude that there is a positive though not significant relationship between employee commitment and pay scales. In other words, the level of the individual to commit to work at the organization in the future does not have impact on the likelihood they are to be rewarded for creating value for their organization.

This finding is counter-intuitive and is also explained by the peculiar nature of the workforce at the research project organization (RPO), as explained above.

There are two significant findings from the regression analyses as shown in Table 3. The first crucial finding is that when predicting the value of work created by human capital (i.e. activity levels), the employee capability and psychological contract are both important. The results showed that, employees with higher level of psychological contract (PC) would be more motivated to work on important tasks; particularly those employees with high employee satisfaction (HC2). This is an important finding which confirms the importance of employee morale on productivity. It provides intellectual capital theory with managerial application by allowing measurement of morale (HC2) and a way to link this with productivity (activity).

The second crucial finding is, when predicting pay scale, HC1 is the only significant variable. That is, consistent with conventional belief; an employee with higher level of basic human capital such as more experience, higher level of skills, or knowledge, would be regarded as a more contributing member of the organization and therefore rewarded with higher level of salary. However, there is no positive relationship between the two psychological contract variables - employee satisfaction (HC2) and employee commitment (HC3) - and pay. Employee commitment actually has a significant negative relationship with pay, however, this occurs when significant proportions of senior staff are ready to retire and may be explained as normal organizational behaviour for those with an ageing workforce demographic. However, the finding that employee satisfaction has no relationship with pay scales is concerning within the context of the conceptualisation of human capital presented in this paper. The implications are discussed next.

\section{Discussion}

The literature review identified several themes. We began by examining current research directions in intellectual capital (IC). We focused on practice and how IC can be used to help managers; particularly how IC conceptualizations can help manage IC resources (as opposed to measure resources). The proxy for managing IC resources used in this paper is improved employee 
compensation. This is one of the five main reasons why organisations measure and report their IC (Marr, 2003). The benefit for managers in using our conceptualization of IC to improve employee compensation is strategic alignment (SA).

Given this special issue of the JIC examines the public sector, we then turned to relevant literature in this domain. We argued that our conceptualization of human capital (HC) will have most benefit for the public sector in terms of increased innovation. Using Dumay and Rooney's (2011) study of Lands as the platform, we feel that IC can most help the public sector by improving organizational learning. For example, Lands focused on narratives of achievement as a way to report on how the organization was learning and, therefore, growing its IC. In our experience, public sector organizations are increasingly using performance management scorecards, such as the Balanced Scorecard. The learning \& growth (L\&G) dimension of the Balanced Scorecard is the weakest of the four dimensions; in terms of empirical evidence on how to measure and manage its performance. We position our HC conceptualization as a way to improve the $L \& G$ dimension of the Balanced Scorecard. This provides our method with a 'home', i.e., Balanced Scorecard reporting, and a tangible organizational benefit, i.e. increased creativity and innovation. The link to strategic alignment (SA) provides a further framework for managers to see how to use our HC conceptualization for organizational benefit. The challenge for the public sector in this discussion is how to act on the issues underlying SA found in this paper, i.e. how can an organization often constrained by employee compensation rules (i.e. award payments) attain SA? We argue that the public sector must consider more flexible pay systems, such as merit increases and variable pay (see Arthur, 2001) in order to achieve distributive and procedural justice for its employees. Otherwise public sector organizations will continue to suffer strategic misalignment and unsatisfactory creativity and innovation.

Finally, we presented literature on conventional views of human capital (HC) and our new conceptualization of HC. Our conceptualization has an action focus. While our first HC construct employee capability (HC1) - establishes the potential of an individual to create value for their organization, the two other constructs - employee satisfaction (HC2) and employee commitment (HC3) - establish the individual's willingness to use their capability to benefit the organization. This conceptualization links with the other themes in the literature review in this way. First, we argue that improved employee compensation will increase employee satisfaction and employee commitment. People who perceive distributive and procedural justice in employee compensation will be happier and want to stay. They will, therefore, use their HC to create value for their organization via increased creativity and innovation. Second, the HC conceptualization will measure the organization's learning performance and also enable growth in performance. This may occur by 
using the $\mathrm{HC}$ conceptualization to understand the strategic alignment (SA) of the workforce. Misalignment means unsatisfactory employee compensation and, therefore, low scores in either HC2 (employee satisfaction) or HC3 (employee commitment) or both. Our conceptualization provides managers with the tools to take action, i.e., intellectual capital in practice, to attain SA and then increase creativity and innovation.

Next, we present the overall findings against the five research questions within the context of the themes from the literature review outlined above; then draw general conclusions; and finally look at managerial implications.

\section{Research Question 1}

The paper's first finding is partial support that psychological contract has a direct positive relationship with innovation. The results show that hypotheses $\mathbf{H}_{1}$ a and $\mathbf{H}_{\mathbf{1}} \mathbf{b}$ are partially supported (two of the three variables). This indicates the individual's emotional relationship with the organization - psychological contract measured by employee satisfaction ( $\mathrm{HC2}$ - - has a positive and significant relationship with employee capability (HC1) and the way the individual is recognised (activity) for creating value for the organization. However, there is no significant positive relationship in the way the individual is rewarded (pay scales) for creating value for the organization.

The latter finding reveals a significant problem for the research project organization (RPO). The relationship between the study's dependent and independent variables indicates partial strategic alignment (SA). The outcome of SA is innovation, that is, positive use of the organizations human capital to generate creativity, sharing, and usage of employee capability. While there is good news for the RPO in terms of how it gets value from its staff ( $\mathrm{HC1}, \mathrm{HC2}$, and activity); it is not adequately rewarding staff for value ( $\mathrm{HC1}, \mathrm{HC2}$, and pay). This indicates strategic misalignment due to distributive injustice in employee compensation. This could lead to low morale, motivation, productivity, and employee turnover.

\section{Research Question 2}

The paper's second finding is that employee capability (HC1) had a direct positive relationship with the work activity level. This supports hypotheses $\mathbf{2}$. This means that intellectual capital in practice may use the employee capability (HC1) measurement presented in this paper to ensure the right people are doing the right work. This will improve productivity. 


\section{Research Question 3}

The paper's third finding is that employee satisfaction ( $\mathrm{HC2}$ ) had a direct positive relationship with the work activity level. This supports hypotheses $\mathrm{H} 3 \mathrm{a}$. This means that intellectual capital in practice may use the employee satisfaction ( $\mathrm{HC2}$ ) measurement presented in this paper to ensure job satisfaction is created from people doing the right work. This will reduce employee turnover.

The paper's fourth finding is that employee commitment (HC3) had a direct negative relationship with work activity level. This does not support hypothesis $\mathrm{H}_{3} \mathbf{b}$. This means that intellectual capital in practice may use the employee commitment HC3 measurement presented in this paper to ensure people who intend to leave the organization are not doing important work. This will reduce corporate risk of poor performance in important activities.

Research Question 4

The paper's fifth finding is that employee capability (HC1) has a direct positive relationship with pay. This supports hypothesis $\mathbf{H}$. This means that intellectual capital in practice may use the employee capability ( $\mathrm{HC} 1)$ measurement presented in this paper to ensure people are rewarded for creating value from their work. This will improve motivation.

\section{Research Question 5}

The paper's sixth finding is that employee satisfaction (HC2) and employee commitment (HC3) had no relationship with pay. This does not support hypotheses $\mathrm{H}_{5} \mathbf{a}$ and $\mathrm{H}_{\mathbf{5}} \mathbf{b}$. This means that intellectual capital in practice may use the employee satisfaction (HC2) and employee commitment (HC3) measurements presented in this paper as opportunities for further research about ensuring people are rewarded for their attitude (employee satisfaction) and loyalty (employee commitment). This will improve organizational culture.

The research project organization (RPO) is Australia's second largest government department. It has some very interesting characteristics which may be shared by other public sector organizations and make the results more generalizable including:

- $\quad$ a skilled workforce

- $\quad$ an ageing workforce

- strong vocational commitment and sense of job-related identity from employees

- a bureaucratic organizational structure and control system

- the threat of knowledge loss 
The results of this research project investigating the $\mathrm{HC}$ within the RPO are informative for public sector managers; particularly those with the characteristics listed above. If they can be summarised generally, the statistical analysis demonstrated three main findings. First, the disaggregation of HC into three factors: HC1 (employee capability), HC2 (employee satisfaction), and HC3 (employee sustainability/commitment) proved helpful in understanding how HC may be managed. This contributes to the agenda for research into intellectual capital in practice by introducing three new 'other factors' to help operationalise intellectual capital and make it more relevant for practitioners.

Second, the results showed that there is a positive relationship between two of the three HC constructs and the input for organizational value (work activity). This means that employees that have capability and motivation will want to work on important work activities, therefore creating value for the organization. The highest value employees, in terms of $\mathrm{HC}$ as we define it in this paper, worked on the highest value creating activities for the RPO, thereby creating strategic alignment (e.g. see Kaplan and Norton, 2006). They had the right people with the right knowledge in the right jobs.

On the other hand, there was a direct negative relationship between employee commitment and work activity. This is surprising because we expected that employees with strong commitment would do the highest value activities. Yet the reverse occurred at the RPO. Those with the weakest organizational commitment were doing the most important work. However, on closer examination, the finding makes sense. Over the course of the data gathering (surveys) (2009-2011), the RPO lost a significant proportion of its most experienced staff due to retirement. These employees spent most of their time doing the most important work because of their experience. Understandably, given they were due to retire, their long-term commitment towards the organization was low.

Third, the results show a conflicting relationship between the three $\mathrm{HC}$ constructs and the output for organizational value (pay). While the RPO had a direct positive relationship between HC1 and pay, there was no relationship between the other $\mathrm{HC}$ constructs $-\mathrm{HC} 2$ and $\mathrm{HC}$. This means that while employees are doing the work they should, and the RPO is getting maximum value from its staff; they are not being equitably rewarded. In other words, there are employees who are happy, motivated, committed, and productive, who are getting paid less than employees who are unhappy, unmotivated, uncommitted, and unproductive. This may create perceptions of inequity.

Employees have two major needs with regard to pay. The first is for pay to be distributed equitably within the organization (Phillips and Connell, 2003). This is called distributive justice. If employees feel that the organization has a fair distribution of pay, the employees' intent to leave is lower than those who feel pay is unfairly distributed (Liang, 2000). Second, employees need to understand the 
process through which pay is administered. If problems with the administration and delivery of pay occur, employees need to be able to address organizational procedures. This is called procedural justice. This addresses employees' perception about pay inequality and the extent to which employees understand how performance affects salary. Procedural justice occurs when employees have the right to appeal unfair pay practices.

\section{Managerial Application}

Our discussion then focuses on how our HC model may be used in the public sector to improve innovation. We suggest that the research presented in this paper has three main implications for public sector managers. We present new ways to (1) measure the value of staff, (2) align the workforce, and (3) reward value creation. If public sector managers adopt the HC model presented here, improved innovation should occur via increased intellectual capital efficiency; more specifically, increased motivation and employee retention. Each of these implications are discussed separately.

The first implication from this paper is that public sector managers can use the $\mathrm{HC}$ model to measure the value of staff in a new way. In our experience at the research project organization (RPO), the Australian public sector measures staff in terms of numbers and cost, i.e., staff salary budget. Employee capability is the way that the public sector typically recognises the value of its employees via salary and seniority. The research findings confirm that employee capability is an effective measure. There was a direct positive relationship between employee capability and pay, and between employee capability and work activity. This means that the RPO correctly matched employee capability with the value created by employees (work) and how they were rewarded for this activity (work). Employees were allocated more important work and were given higher pay as they gain higher employee capability scores. However, our new conceptualization of HC showed that the psychological contract is also important in measuring the value of employees. The two PC factors combine to motivate employees to use their HC1 to create value for the organization. Evidence was provided by the fact the two PC factors also had a direct positive relationship with value creation (work activity).

The second implication was that the HC model presented in this paper may help public sector organizations achieve strategic alignment (SA) of their workforce. SA is most commonly discussed in the literature as a tool to formulate and implement a corporate strategy. Tools such as Activity Based Costing and the BSC (Kaplan and Norton $(1996,1996 \mathrm{~b}, 2006)$ are proposed as effective 
management control systems that enable strategy implementation. In the public sector, control is important as a means of ensuring employees provide service delivery the organization is being funded for and that they follow standard operating procedures and work correctly. SA tools provide information to monitor whether the organization is achieving its strategic goals (Senshu and Souissi, 2012). From an organisation-wide perspective, the main practical outcome of SA is synergy. Synergy is created by business units combining to produce more value for the organization than the sum of their individual parts, i.e. $1+1=$ more than 2 . Alignment ensures there is minimal waste, duplication, and also organisational learning benefits. The research findings found that the RPO had $\mathrm{SA}$, in the sense that there was a direct positive relationship between $\mathrm{HC} 1$ and $\mathrm{HC} 2$ and work activity. This means that the RPO correctly matched employee capability (HC1) and motivation (HC2) with the value created by employees (work). SA meant that the right employees were doing the right work. However, there were problems in the findings for the third construct - employee commitment (HC3). The RPO had not correctly matched commitment with recognition (activity) or reward (pay). This meant that the third part of perfect SA was missing - the RPO did not have the right employees doing the right work at the right time. This meant the RPO was not getting maximum benefit from its $\mathrm{HC}$ allowing innovation. This occurred due to a peculiarity in the sample where some of the RSO's most experienced employees - who were doing the most important work due to their experience had low commitment because they intended to retire soon. Only when it had staff with the highest organizational commitment aligned with $\mathrm{HC} 1$ and $\mathrm{HC} 2$ and activity and pay would the RPO achieve maximum benefit from SA.

The third implication was that public sector should reward employees for all three HC factors, not just HC1, or the organization risks decreased psychological contract, decreased SA, and, ultimately, employee turnover. Many organizations have found that the sole reliance on financial measurements will lead to short-term results (Johnson and Kaplan, 1987; Kaplan and Norton, 1992) if those measures are linked to the compensation system (Bushman et al., 1995). An increasing number of studies suggest that non-financial performance measures are better predictors of longterm performance and thus should be used to help refocus managers on the long-term aspects of their decisions (Ittner et al., 2003). Most employees feel that they are worth more than they are actually paid (Phillips and Connell, 2003). There is a natural disparity between what people think they should be paid and what organizations spend in compensation. When the difference becomes too great and another opportunity occurs, turnover can result. The intellectual capital in practice presented in this paper, that is, the conceptualization of HC, may address these issues and help managers improve procedural and distributive justice in terms of how employees and recognised (activity) and rewarded( pay scales) for their innovation. Organizations may reward employees for 
more than just employee capability (HC1). Both employee capability (HC1) and employee satisfaction ( $\mathrm{HC} 2$ ) both have positive and significant effects on work activity level. The negative results of employee commitment $(\mathrm{HC} 3)$ reflect a peculiarity in our sample (senior employees due to retire). We feel the logic that employees with strong organizational commitment should be allocated important work still applies, and this may be opportunity for further research.

In terms of pay solutions, two of the most interesting in relation to intellectual capital are (1) merit increases and (2) variable pay. Merit increases are annual salary increases, often following a performance evaluation, where the employees' performance is rewarded through a formal evaluation system (Arthur, 2001). Variable pay is an incentive or bonus plan designed to reward the achievement of the employee against performance objectives irrespective of pay schedule or level (Arthur, 2001). The use of pay schedules, such as awards, make it challenging for public sector organizations to introduce such schemes. However, our research findings suggest that public sector managers need to address procedural injustice in regards to pay by recognising the PC factors and rewarding them through creative pay solutions such as merit increases or variable pay.

\section{Conclusions}

This paper aimed to contribute to the third wave of intellectual capital research by looking at how IC is or can be used. We have focused on how managers can use human capital (HC) to achieve strategic alignment (SA). By introducing psychological contract as 'other factors' in the measurement of HC, we have explained how intellectual capital theory can be extended to help managers understand how to align their workforce. In showing how intellectual capital in practice can benefit public sector organizations, we have followed the direction set by Dumay and Rooney (2011), and Dumay and Tull (2011) in IC's transition from measurement to action by exploring how our conceptualization of human capital can improve innovation via SA.

We contribute to this research direction in two ways. First, we improve the reporting of intellectual capital. Our human capital conceptualization aimed to improve the learning and growth dimension of the Balanced Scorecard (BSC). Dumay and Rooney (2011) found that their research study organization, Lands, achieved the transition for IC from measurement to action by adapting the BSC to suit their needs. Public sector organizations are increasingly using performance management frameworks, such as the BSC, to manage and report on their strategy. This also helps them with the timeliness of IC reporting. By using our HC method to improve the BSC, public sector organizations could better report changes in the strategic alignment (SA) of their workforce. This could result in 
more frequent disclosure of IC and would provide higher immediacy value (see Dumay and Tull, 2007), which is particularly relevant if our aim is to improve perception of IC in practice.

Second, we contribute to the need for intellectual capital theory to help managers take action to improve their organization's performance. We feel that intellectual capital can most help the public sector by improving organizational learning. In the literature review, we stated that Dumay and Rooney (2011) pose the very interesting question: Is intellectual capital measurement necessary for the effective management of intellectual capital? They link this discussion to Drucker's (1954) pioneering concept of management by objectives. The focus on measuring intellectual capital seems to have been driven by a loose assumption that what gets measured gets managed. However, there is increasing doubt that the measurement of intellectual capital, in isolation, creates value. We address this problem by showing how managers can use our HC conceptualization to take action to track change in terms of strategic alignment and improve organizational learning. Our approach does include measurement of $\mathrm{HC}$, so it answers the question above by suggesting that measurement is part of managing intellectual capital. However, the key challenge for intellectual capital research is to help managers take action. Our HC conceptualization does this by providing answers to these questions posed by managers: Are employees doing the right work at the right time? If not there are competency gaps which may be addressed by targeted learning. Are employees using their human capital to create value for their organization? If not their psychological contract must be addressed.

The conceptualization of $\mathrm{HC}$ presented in this paper has an action focus. While the first $\mathrm{HC}$ construct - employee capability (HC1) - establishes the potential of an individual to create value for their organization, the two other constructs - employee satisfaction (HC2) and employee commitment (HC3) - establish the individual's willingness to use their capability to benefit the organization. This conceptualization links with the themes in the literature review in this way. First, we argue that improved employee compensation will increase employee satisfaction and employee commitment. People who perceive distributive and procedural justice in employee compensation will be happier and want to stay. They will, therefore, use their $\mathrm{HC}$ to create value for their organization via increased creativity and innovation. Second, the HC conceptualization will measure the organization's learning performance and also enable growth in performance. This may occur by using the $\mathrm{HC}$ conceptualization to understand the strategic alignment (SA) of the workforce. Misalignment means unsatisfactory employee compensation and, therefore, low scores in either HC2 (employee satisfaction) or HC3 (employee commitment) or both. Our conceptualization provides managers with the tools to take action (i.e. intellectual capital in practice) to attain SA and then increase creativity and innovation. 
In summary, the paper's findings provide managers with a method to align the value created by HC (work activity) and how this is rewarded (pay). There were five research questions. Research Question 1 - that psychological contract has a direct positive relationship with innovation - was partially supported. While there is good news for the RPO in terms of how it gets value from its staff ( $H C 1, H C 2$, and activity); it is not adequately rewarding staff for value ( $H C 1, H C 2$, and pay). Research Question 2 - that employee capability ( $\mathrm{HC1}$ ) had a direct positive relationship with the importance of work activity - was supported. Research Question 3 - that psychological contract (HC2 and HC3) has a direct positive relationship with work activity - was partially supported. Employee satisfaction (HC2) has a positive relationship with activity level; however, employee commitment (HC3) had a direct negative relationship with activity level. Research Question 4 - that employee capability (HC1) has a direct positive relationship with the pay - was supported. Research Question 5 - that psychological contract ( $\mathrm{HC} 2$ and $\mathrm{HC} 3$ ) has a direct positive relationship with the pay - was not supported. Neither employee satisfaction (HC2) nor employee commitment (HC3) had a significant positive relationship with pay scales.

intellectual capital in practice may be achieved by using these findings to create maximum value from innovation via strategic alignment of the workforce as follows: research question 1 examines positive use of the organization's human capital to generate creativity, sharing, and usage of employee capability; research question 2 examines how to improve productivity; research question 3 explores how to reduce employee turnover and reduce corporate risk of poor performance in important activities; research question 4 examines how to improve motivation; and research question 5 poses how to improve organizational culture.

The findings present an interesting dilemma. The results show that the RPO is aligned in terms of the value created by its $\mathrm{HC}$. Employee capability ( $\mathrm{HC} 1)$ and motivation $(\mathrm{HC})$ are matched with the level of value they are creating, i.e. the importance of work activity. Ideally, individuals that are highest in terms of $\mathrm{HC} 1, \mathrm{HC} 2$, and HC3 are doing the most important work. Employees who are most able to do this work, want to do it, and see a purpose in doing it; should be spending their time in the most efficient and productive way for their organization. Alternatively, those who are less capable, motivated, and committed, should be doing less important work. Managers can use the method to measure the SA of their $\mathrm{HC}$ in terms of value creation (work activity).

There is a dilemma presented by the fact that the RPO's pay schedule does not match its value creation. In other words, employees are not being rewarded for their contribution to the organization's performance. We know this because only employee capability is positively related to pay. Employee satisfaction and employee commitment are not related to pay. This means that employees with strong psychological contract (PC) may be paid less than others with weak PC. The 
implications become clearer when we combine pay with work activity. While these strong PC employees are being asked to do important work, they are not always being paid at the rate of colleagues doing similar work. This will create perceptions of distributive injustice (Phillips and Connell, 2003), which will make those with strong PC unhappy, thereby decreasing their PC, disrupting the SA of the value creation, and lead to employee turnover. Ultimately, the employees who have the highest HC efficiency, because they are creating most value for the least pay, may leave the organization if their sense of unfairness and inequity about their pay is not addressed. Managers can address this problem by using the HC conceptualization outlined in this paper to introduce procedural justice (Phillips and Connell, 2003) for employees to argue for higher pay. Methods such as merit increases and variable pay (Arthur, 2001) might be introduced. While this is problematic for public sector organizations often constrained by having to fit salary awards, innovative organizations are increasingly considering more flexible pay systems. This paper has suggested how public sector managers might consider strategically aligning their HC with a new focus on the emotional relationship with the organization (PC). 


\section{BIBLIOGRAPHY}

Abeysekera, I. (2013), "A template for integrated reporting”, Journal of Intellectual Capital, Vol. 14 No. 2, pp. 227-245.

Argyris, C., (1960), Understanding Organizational Behavior, Dorsey Press, Michigan.

Arthur, D., (2001), The Employee Recruitment and Retention Handbook, American Management Association, New York, NY.

Blau, P.M. (1964). Exchange and Power in Social Life, Wiley, New York.

Bontis, N. (1998), "Intellectual capital: an exploratory study that develops measures and models", Management Decision, Vol. 36 No. 2. pp63-76.

Bontis, N., (2002), "Managing organisational knowledge by diagnosing intellectual capital: Framing and advancing the state of the field", in Choo, C.W. and Bontis, N. (Editors), The Strategic Management of Intellectual Capital and Organizational Knowledge, Oxford University Press, New Yorkpp621-42.

Bushman, R.M., Indjejikian, R.J. and Smith, A. (1995), “Aggregate performance measures in business unit manager compensation: the role of intrafirm interdependencies", Journal of Accounting Research, Vol. 33. pp101-28

Carson, E, Ranzijn, R, Winefiel, A \& Marsden, H (2004), “Intellectual capital: Mapping employee and work group attributes”, Journal of Intellectual Capital, Vol. 5. No. 3. pp443-461

Chew, J. and Chan, C.A.; (2008), Human resource practices, organizational commitment and intention to stay, International Journal of Manpower, Vol. 29 No. 6. pp503-522.

Cleary, P. (2009), “Exploring the relationship between management accounting and structural capital in a knowledge-intensive sector", Journal of Intellectual Capital, Vol. 10 No. 1, pp. 37-52.

Drucker, P.F. (1954), The Practice of Management, HarperCollins, New York, NY.

Dumay, J. and Tull, J.A.; (2011), Intellectual capital disclosure and price-sensitive Australian Stock Exchange announcements, Journal of Intellectual Capital Vol. 8 No. 2, 2007 pp. 236-255

Dumay, J. and Rooney, J.; (2011), "Measuring for managing?" An IC practice research project, Journal of Intellectual Capital, Vol. 12 No. 3, 2011 pp344-355

Dumay, J. and Garanina, T. (2013), "Intellectual capital research: a critical examination of the third stage", Journal of Intellectual Capital, Vol. 14 No. 1, pp. 10-25.

Dumay, J.; (2014), "15 years of the Journal of Intellectual Capital and Counting: A manifesto for transformational IC research", Journal of Intellectual Capital, Vol. 15 No. 1. Pp. 2-37

Edvinsson, L., Dvir, R., Roth, N., Pasher, E., (2004), "Innovations: The new unit of analysis in the knowledge era", Journal of Intellectual Capital”, Vol. (5). No. 1. Pp4-58.

Eisenberger, R., Fasolo, P. \& Davis-LaMastro, V., (1990). “Perceived organizational support and employee diligence, commitment, and innovation", Journal of Applied Psychology, Vol. 75 No. 1. pp51-59

Grant, R., (2014), Contemporary Strategy Analysis, Wiley, West Sussex, U.K.

Guthrie, J. and Petty, R. (2000), "Intellectual capital: Australian annual reporting practices", Journal of Intellectual Capital, Vol. 1 No. 3, pp. 241-51.

Guthrie, J., Petty, R. and Ricceri, F. (2006), "The voluntary reporting of intellectual capital. Comparing evidence from Hong Kong and Australia”, Journal of Intellectual Capital, Vol. 7 No. 2, pp. 254-71. 
Guthrie, J., Ricceri, F. and Dumay, J. (2012), "Reflections and projections: a decade of intellectual capital accounting research", British Accounting Review, Vol. 44 No. 2, pp. 68-92.

Hair, J.F., Anderson, R.E., Tatham, R.L. and Black, W.C. (1995) Multivariate Data Analysis, PrenticeHall: New Jersey.

Homans, G.C. (1961), Social Behaviorism, Harcourt Brace and World, New York.

Ittner, C.D., Larcker, D.F. and Meyer, M.W. (2003), "Subjectivity and the weighting of performance measures: evidence from a balanced scorecard”, The Accounting Review, Vol. 78 No. 3. pp725-58

Johnson, H.T. and Kaplan, R.S. (1987), Relevance Lost: The Rise and Fall of Management Accounting, Harvard Business School Press, Boston, MA.

Kaplan, R.S. and Norton, D.P. (1992), "The Balanced Scorecard - measures that drive performance", Harvard Business Review, Vol. 70 No. 1. pp71-9

Kaplan, R.S. and Norton, D.P. (1996), The Balanced Scorecard: Translating Strategy into Action, Harvard Business School Press, Boston, MA.

Kaplan, R.S. and Norton, D.P. (2006), Alignment: Using the Balanced Scorecard to Create Corporate Strategies, Harvard Business School Press, MA.

Liang, K.G.; (2000), Dissertation Abstracts International: Section B: The Sciences and Engineering, 60 (11-B): 5818.

Marr, B. (2003), "Why do firms measure their intellectual capital?", Journal of Intellectual Capital, Vol. 4 No. 4, pp. 441-64.

Massingham, P.; and Diment, K.; (2009), Organizational Commitment, Knowledge Management Interventions, and Learning Organization Capacity'?", The Learning Organization. Vol. 16 No. 2: pp $122-142$

Massingham, P.; (2015), Knowledge Accounts, Long Range Planning (forthcoming).

McNabb, D.E., (2007), Knowledge Management in the Public Sector: A blueprint for innovation in the government, M.E. Sharpe, Armonk, New York.

Nunally, J.C. (1978), Psychometric Theory, 2nd Edition, McGraw-Hill, New York.

Phillips J.J., and Connell, A.O., (2003), Managing Employee Retention: a strategic accountability approach, Elsevier Butterworth Heinmann, Ney York, NY.

Porter, L., Steers, R. \& Mowday, R., (1973), “Organizational commitment, job Satisfaction, and turnover among psychiatric technicians", Journal of Applied Psychology, Vol. 59 No. 5. pp603-609

Riggs, M.L., Warka, J., Babasa, B., Betancourt, R., and Hooker, S.; (1994), “Development and Validation of Self-Efficacy and Outcome Expectancy Scales for Job-Related Applications", Educational and Psychological Measurement, Vol. 54 No. 3. pp793-802

Robinson, S.L., and Rousseau, D.M., (1994), "Violating the psychological contract: Not the exception but the norm", Journal of Organizational Behavior, Vol. 15. No. 3. Pp245-259.

Rousseau, D.M., (2001), "Schema, promise, and mutuality: The building blocks of the psychological contract" Journal of Occupational and Organizational Psychology, Vol. 74. No. 4. Pp511-541.

Senshu, K.I.; and Souissi, M.; (2012), "Managerial Accounting as a Tool for Corporate Strategy: Synergy Creation and Anergy Inhibition"; Journal of International Business Research, Vol. 11 No. 1 pp63-72. 
Sillanpa“ a“ , V., Lo“ nnqvist, A., Koskela, N., Koivula, U.-M., Koivuaho, M. and Laihonen, H. (2010), "The role of intellectual capital in non-profit elderly care organizations", Journal of Intellectual Capital, Vol. 11 No. 2, pp. 107-22

Spector, P.E., (1988), "Development of the work locus of control scale", Journal of Occupational Psychology, Vol. 61. No. 4. Pp335-340.

Stewart, T.A. (1997), Intellectual Capital - The New Wealth of Organizations, Doubleday Publishing, New York, NY.

Sturges, J., Conway, N., Guest, D. and Liefooghe, A. (2005), “Managing the career deal: the psychological contract as a framework understanding career management, organizational commitment and work behaviour", Journal of Organizational Behavior, Vol. 26. pp821-38.

Sveiby, K.E., (1997), The New Organizational Wealth: Managing \& Measuring Knowledge-based Assets, San Francisco: Berrett-Koehler Publisher

Whyte, M. and Zyngier, S., (2014) "Applied Intellectual Capital Management: Experiences from an Australian public sector trial of the Danish Intellectual Capital Statement", Journal of Intellectual Capital, Vol. 15 No.2, pp.227-248

Workman, M. and Bommer, W. (2004), “Redesigning computer call center work: a longitudinal field experiment", Journal of Organizational Behavior, Vol. 25: 317-37.

\section{Author biographies}

Dr Peter Massingham

Peter is from the University of Wollongong's School of Management, Operations and Marketing within the Faculty of Business. Before joining the University in 1998, he was a management consultant, most recently with KPMG. He works with a range of Australian organisations on their business strategy, particularly focusing on knowledge management. Most recently he has completed a major research projects with the Australian Department of Defence on knowledge loss (20082013) and Saudi Arabia Government on their research institutes (2008-2012).

Associate Professor Leona Tam

Leona Tam is an Associate Professor of Marketing at the Faculty of Business, University of Wollongong, Australia. Her research interests lie in behavioral recurrence including habit, loyalty, and implementation plans in personal finance and health contexts. She also studies motivational consumer psychology. Her work has been published in marketing and psychology journals including Journal of Marketing, Psychological Science, Journal of Personality and Social Psychology, and Organizational Behavior and Human Decision Processes.

\section{Acknowledgement}

The authors with to acknowledge the support of the Australian Research Council and the Department of Defence for support of the research project associated with this paper. 


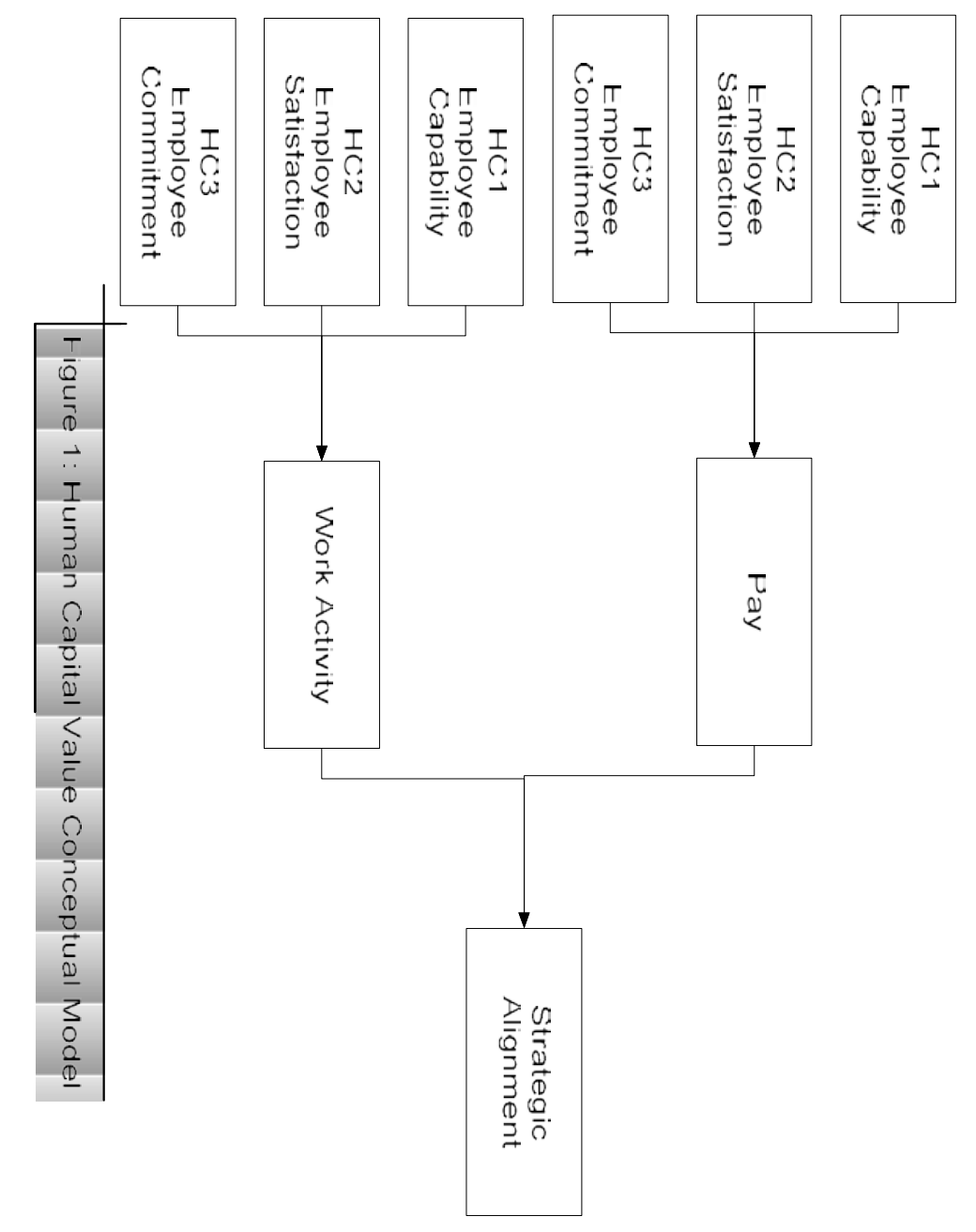




\begin{tabular}{|c|c|c|c|c|}
\hline Measure & Definition & Example items & $\begin{array}{c}\text { Previous Reliability } \\
\text { Testing }\end{array}$ & $\begin{array}{c}\text { Our Reliability } \\
\text { Testing }\end{array}$ \\
\hline \multicolumn{5}{|c|}{ Employee Capability (HC 1) } \\
\hline Qualifications & $\begin{array}{l}\text { Qualification was measured by the number of qualifications } \\
\text { and their ranking points. The logic is that the more } \\
\text { qualifications the better, but they have to be relevant. } \\
\text { Ranking measures relevance in terms of the individual's } \\
\text { current job, as well as the time required to gain the } \\
\text { qualification. Qualifications were allocated points - the } \\
\text { more relevant and the longer to study - the more points. } \\
\text { Employees with more relevant qualifications are more } \\
\text { valuable. }\end{array}$ & $\begin{array}{l}\text { Trade certificates: } 5 \text { points for } \\
\text { each certificate. Maximum of } 25 \\
\text { points } \\
\text { Undergraduate university } \\
\text { degree: } 75 \text { points for a relevant } \\
\text { degree (i.e. Engineering / } \\
\text { Technology / Computer), } 50 \\
\text { points for a non-relevant degree }\end{array}$ & $\begin{array}{l}\text { No previous empirical } \\
\text { testing. }\end{array}$ & $\begin{array}{l}\text { Face validity was } \\
\text { used. }\end{array}$ \\
\hline Experience & $\begin{array}{l}\text { Experience was measured by the length of time necessary to } \\
\text { learn the job (incumbent experience), how difficult it is to } \\
\text { learn the job (understanding) and how difficult it is to teach } \\
\text { the job (transmission). Employees with experience, in jobs } \\
\text { where tacit knowledge is important, are more valuable. }\end{array}$ & $\begin{array}{l}\text { "Work experience aside, what } \\
\text { proportion of your job could be } \\
\text { done by an unskilled worker?" } \\
\text { "If another person of similar } \\
\text { qualifications but limited } \\
\text { workplace experience was in } \\
\text { your job, what proportion of it } \\
\text { would they be able to learn by } \\
\text { reading documentation?" }\end{array}$ & $\begin{array}{l}\text { No previous empirical } \\
\text { testing. }\end{array}$ & $\begin{array}{l}\text { Found to have } \\
\text { satisfactory } \\
\text { coefficient alphas of } \\
.77 \text {. }\end{array}$ \\
\hline Skills & $\begin{array}{l}\text { Skills was measured by six factors: staff quality, personal } \\
\text { efficacy, professional capabilities, learning goal orientation, } \\
\text { learning motivation, and learning confidence. The logic was } \\
\text { that skills involve a combination of current capability and } \\
\text { willingness to increase that capability through continual } \\
\text { learning. The first three factors represent current capability, } \\
\text { while the second three factors represent future capability or } \\
\text { willingness to learn/increase current capability. Employees } \\
\text { with high skill levels, and willingness to increase those skills } \\
\text { further, are more valuable. }\end{array}$ & $\begin{array}{l}\text { "I have confidence in my ability } \\
\text { to do my job" } \\
\text { "I am able to deliver the quality } \\
\text { of service expected by my } \\
\text { customers" } \\
\text { "I am keen to use the learning } \\
\text { and development opportunities } \\
\text { available to me" }\end{array}$ & $\begin{array}{l}\text { No previous empirical } \\
\text { testing. }\end{array}$ & $\begin{array}{l}\text { Found to have } \\
\text { satisfactory } \\
\text { coefficient alphas of } \\
.83 \text {. }\end{array}$ \\
\hline Knowledge & $\begin{array}{l}\text { Knowledge is measured by self-assessment (levels of } \\
\text { knowledge by activity on a scale of 1-9), the degree of } \\
\text { tacitness of their knowledge, the level of complexity of the } \\
\text { knowledge, and level of consistent interpretation with other }\end{array}$ & $\begin{array}{l}\text { Rate competence in activities } \\
\text { using a nine step level e.g. } \\
\text { Level 3: Know basics of what to } \\
\text { do: Can explain how to do the }\end{array}$ & $\begin{array}{l}\text { No previous empirical } \\
\text { testing. }\end{array}$ & $\begin{array}{l}\text { Face validity was } \\
\text { used. }\end{array}$ \\
\hline
\end{tabular}




\begin{tabular}{|c|c|c|c|c|}
\hline & $\begin{array}{l}\text { subject matter experts about the nature of the knowledge. } \\
\text { In this way, the questions measure respondents' perspective } \\
\text { about their knowledge in the work they do but was also } \\
\text { validated by the responses of other people doing this work. } \\
\text { Employees with high knowledge levels, validated by } \\
\text { consistent interpretation with other staff, are more valuable. }\end{array}$ & $\begin{array}{l}\text { activity in very basic terms. } \\
\text { Level 6: Can control performance } \\
\text { (I.e. do it consistently well): } \\
\text { Show good awareness of impact } \\
\text { of having done a good job } \\
\text { Validated by peer assessment. }\end{array}$ & & \\
\hline \multicolumn{5}{|c|}{ Employee Satisfaction (HC 2) } \\
\hline Affective attachment & $\begin{array}{l}\text { Affective attachment measures the emotional relationship } \\
\text { between the employee and the organisation. The stronger } \\
\text { the attachment, the more the individual is satisfied. It } \\
\text { measures whether people like their organisation, reflecting } \\
\text { the difference between what the employees want from their } \\
\text { job and what they perceive it as offering. Employees with } \\
\text { high affective attachment levels - who really like where they } \\
\text { work - are more valuable. }\end{array}$ & $\begin{array}{l}\text { "I feel a strong sense of } \\
\text { belonging to the RPO" } \\
\text { "I would be happy to work at the } \\
\text { RPO until I retire" }\end{array}$ & $\begin{array}{l}\text { Eisenberger et al } \\
(1990) \text { reported high } \\
\text { internal validity. The } \\
\text { alpha coefficients } \\
\text { ranged from } .81 \text { to } \\
.89 .\end{array}$ & $\begin{array}{l}\text { Found to have } \\
\text { satisfactory } \\
\text { coefficient alpha of } \\
.92 .\end{array}$ \\
\hline Locus of control & $\begin{array}{l}\text { Locus of control concerns people's perceived control of their } \\
\text { lives. People who hold expectancies that they can or cannot } \\
\text { control their work life are considered to be internals, and } \\
\text { people who hold expectancies that outside forces or luck } \\
\text { controls their work are considered to be externals. } \\
\text { Individuals with an external focus of control, who do not } \\
\text { believe they can control important aspects of their } \\
\text { environments, will find the work environment to be more } \\
\text { threatening and stressful. Employees with high locus of } \\
\text { control - i.e. internals (people who feel in charge of their } \\
\text { work life/destiny) - are more valuable. }\end{array}$ & $\begin{array}{l}\text { "A job is what you make of it" } \\
\text { "Most employees have more } \\
\text { influence on their supervisors } \\
\text { than they think they do" }\end{array}$ & $\begin{array}{l}\text { Spector's (1988) scale } \\
\text { is considered the } \\
\text { standard instrument } \\
\text { on locus of control. }\end{array}$ & $\begin{array}{l}\text { Found to have } \\
\text { reasonable coefficient } \\
\text { alpha of } 66 .\end{array}$ \\
\hline Calculative reward & $\begin{array}{l}\text { This is called Expectancy } 2 \text { Theory. Expectancy Theory } 2 \text { is } \\
\text { grounded in the logic that 'if I work hard, I will be rewarded'. } \\
\text { It measures whether people are willing to work hard for } \\
\text { their organisation because they feel they will be rewarded. It } \\
\text { is often called extrinsic rewards. Employees with high } \\
\text { calculative reward levels are more valuable. }\end{array}$ & $\begin{array}{l}\text { "It is more likely that I will be } \\
\text { given a pay raise or promotion } \\
\text { by the RPO if I do high quality } \\
\text { work" } \\
\text { "Getting work done on time is } \\
\text { rewarded by the RPO" }\end{array}$ & $\begin{array}{l}\text { Eisenberger et al } \\
\text { (1990) found alpha } \\
\text { coefficients from . } 81 \\
\text { to } 89 .\end{array}$ & $\begin{array}{l}\text { Found to have } \\
\text { satisfactory } \\
\text { coefficient alpha of } \\
.76 .\end{array}$ \\
\hline Calculative approval & $\begin{array}{l}\text { This is also called Expectancy } 2 \text { Theory. Expectancy Theory } 2 \\
\text { is grounded in the logic that 'if I work hard, I will be } \\
\text { recognised'. It measures whether people are willing to work } \\
\text { hard for their organisation because they feel they will be }\end{array}$ & $\begin{array}{l}\text { "My immediate supervisor pays } \\
\text { added attention to the opinions } \\
\text { of the best workers" }\end{array}$ & $\begin{array}{l}\text { Eisenberger et al } \\
\text { (1990) found alpha } \\
\text { coefficients from . } 81 \\
\text { to } 89 \text {. }\end{array}$ & $\begin{array}{l}\text { Found to have } \\
\text { satisfactory } \\
\text { coefficient alpha of } \\
.76 .\end{array}$ \\
\hline
\end{tabular}




\begin{tabular}{|c|c|c|c|c|}
\hline & $\begin{array}{l}\text { recognised. It is often called intrinsic rewards. Employees } \\
\text { with high calculative approval levels are more valuable. }\end{array}$ & & & \\
\hline $\begin{array}{l}\text { Personal outcome } \\
\text { expectancy }\end{array}$ & $\begin{array}{l}\text { This is called Expectancy } 1 \text { Theory. Expectancy Theory } 1 \text { is } \\
\text { grounded in the logic that 'if I work hard (effort), I will } \\
\text { achieve high performance'. It measures whether the } \\
\text { individual feels their work makes a difference, and is } \\
\text { therefore connected to self-esteem, belief in ability, and } \\
\text { past experiences. Employees with high performance } \\
\text { outcome expectancy levels, those who feel their work is } \\
\text { important and meaningful, are more valuable. }\end{array}$ & $\begin{array}{l}\text { "Making deadlines is easy for } \\
\text { me" } \\
\text { "My work evaluations are } \\
\text { accurate" }\end{array}$ & $\begin{array}{l}\text { Riggs et al. (1994) } \\
\text { reported factor } \\
\text { loadings between } .53 \\
\text { and } .78\end{array}$ & $\begin{array}{l}\text { Found to have } \\
\text { reasonable coefficient } \\
\text { alpha of } 64 .\end{array}$ \\
\hline \multicolumn{5}{|c|}{ Employee Commitment (HC 3) } \\
\hline Trust & $\begin{array}{l}\text { Trust was measured people's trust in their employer. High } \\
\text { trust indicates a strong positive relationship between the } \\
\text { individual and their organisation, high organisational } \\
\text { commitment, and more willingness to stay. Employees with } \\
\text { high trust levels are more valuable. }\end{array}$ & $\begin{array}{l}\text { "The RPO is open and upfront } \\
\text { with me," "I believe the RPO has } \\
\text { high integrity," }\end{array}$ & $\begin{array}{l}\text { Robinson and } \\
\text { Rousseau (1994) } \\
\text { reported an overall } \\
\text { alpha of .93. }\end{array}$ & $\begin{array}{l}\text { Found to have } \\
\text { satisfactory } \\
\text { coefficient alpha of } \\
.84 \text {. }\end{array}$ \\
\hline Careerism & $\begin{array}{l}\text { Careerism measures people's orientation towards their } \\
\text { employer as a stepping stone up the career path. High } \\
\text { careerism sees the organisation as a stepping stone and } \\
\text { individuals focus more on short term rewards such as pay, } \\
\text { training and credentials, while low careerism focuses on the } \\
\text { relationship with the organisation. Employees with low } \\
\text { careerism levels are more valuable. }\end{array}$ & $\begin{array}{l}\text { "I would accept almost any type } \\
\text { of job assignment in order to } \\
\text { keep working for the RPO," } \\
\text { "For me the RPO is the best of } \\
\text { organisation I could work for" }\end{array}$ & $\begin{array}{l}\text { Robinson and } \\
\text { Rousseau (1994) } \\
\text { reported an overall } \\
\text { alpha of } .78 .\end{array}$ & $\begin{array}{l}\text { Found to have } \\
\text { satisfactory } \\
\text { coefficient alpha of } \\
.74 \text {. }\end{array}$ \\
\hline
\end{tabular}


Table 2: Correlation Statistics

\begin{tabular}{|c|c|c|c|c|c|c|c|c|c|c|c|c|}
\hline Mean & (SD) & 1 & 2 & 3 & 4 & 5 & 6 & 7 & 8 & 9 & 10 & 11 \\
\hline \multicolumn{2}{|c|}{1 Qual 31.50 (18.17) } & 1 & .11 & $.21 * *$ & .03 & -.07 & $.17^{* *}$ & $.29 * *$ & $.23 * *$ & -.02 & -.02 & -.01 \\
\hline 2 Experience & \multicolumn{2}{|c|}{$49.73(21.82)$} & & $.27^{* *}$ & $.15^{*}$ & .04 & $.23 * *$ & $.33 * *$ & $.13^{*}$ & .02 & $.19 * *$ & $.14^{*}$ \\
\hline \multicolumn{3}{|c|}{3 Skill $74.51(10.52)$} & & & $.20 * *$ & $.30 * *$ & $.35 * *$ & $.13^{*}$ & $.14^{*}$ & $.36 * *$ & $.36 * *$ & $.35 * *$ \\
\hline 4 Knowledge & $\begin{array}{l}59.69 \\
.03\end{array}$ & 2.99) & & & & & -.01 & .09 & $.13^{*}$ & .12 & .02 & .06 \\
\hline 5 AffAtt & $\begin{array}{l}60.78 \\
.67 * *\end{array}$ & 6.36) & & & & & & $.39 * *$ & $-.13^{*}$ & .01 & $.39 * *$ & $.58 * *$ \\
\hline 6 Locus of & $\begin{array}{l}68.28 \\
.50 * *\end{array}$ & 3.37) & & & & & & & $.52 * *$ & $.25 * *$ & $.47^{* *}$ & $.37^{* *}$ \\
\hline \multicolumn{13}{|l|}{ control } \\
\hline 7 CalRew & $\begin{array}{l}55.95 \\
.10\end{array}$ & $1.57)$ & & & & & & & & $.40 * *$ & $.19^{*}$ & .11 \\
\hline 8 CalApp & $\begin{array}{l}61.23 \\
.05\end{array}$ & 1.75) & & & & & & & & & .07 & .05 \\
\hline 9 PersOut & $\begin{array}{c}66.86 \\
.50 * *\end{array}$ & 1.40) & & & & & & & & & & $.40 * *$ \\
\hline 10 Careerism & $\begin{array}{l}58.88 \\
.55 * *\end{array}$ & 4.38) & & & & & & & & & & \\
\hline 11 Trust & $\begin{array}{l}71.74 \\
1\end{array}$ & $5.73)$ & & & & & & & & & & \\
\hline Pay scale & $\begin{array}{l}86241 \\
.16^{* *}\end{array}$ & 23223) & $-.22 * *$ & $.23^{* *}$ & $.17^{* *}$ & $.23^{* *}$ & .09 & $.27^{* *}$ & $.25 * *$ & -.07 & .02 & .06 \\
\hline Activity 52.26 & $5.86)$ & .12 & $.30 * *$ & .11 & .09 & $-.28 * *$ & $.24 * *$ & $.56 * *$ & $17 * *$ & .05 & .08 & -.04 \\
\hline
\end{tabular}

Note: $* * p<.01, * p<.05$ 
Table 3: Multiple regression results

\begin{tabular}{|c|c|c|c|c|}
\hline \multirow[b]{3}{*}{ Independent variables } & \multicolumn{4}{|c|}{ Dependent variables } \\
\hline & \multicolumn{2}{|c|}{ Pay scale } & \multicolumn{2}{|c|}{ Activity level } \\
\hline & Coefficient & t-statistic Coefficien & & t-statistic \\
\hline Employee Capability (HC1) & 652.44 & $4.12^{* * *}$ & 0.34 & $3.20 * *$ \\
\hline Employee Satisfaction (HC2) & 49.21 & 0.29 & 0.44 & $3.98 * * *$ \\
\hline Employee Commitment ( $\mathrm{HC} 3$ ) & 93.15 & 0.76 & -0.21 & $-2.60 * * *$ \\
\hline \multicolumn{5}{|l|}{ Model summary } \\
\hline Adjusted R-square & & & & 0.13 \\
\hline F-value & & & & $13.00 * * *$ \\
\hline
\end{tabular}

Note: ${ }^{* * *} p<.001, * * p<.01, * p<.05$ 